\title{
ANALISIS PENGENDALIAN INTERNAL PIUTANG USAHA UNTUK MEMINIMALKAN PIUTANG TAK TERTAGIH \\ PT XYZ
}

\author{
Ariyati \\ Sekolah Tinggi Ilmu Ekonomi Wiyatamandala \\ ariyati12312@gmail.com
}

\begin{abstract}
This research aims to identify and analyze the system of internal control of accounts receivable on PT. XYZ to minimize bad debt expense. The research approach used is a descriptive that is used by collecting, compiling, classifying data that they can find out the clear events regarding the problems that have been research. Operational definition used by the internal control system of accounts receivable and bad debt expense. The type of data used is qualitative. Primary and secondary data sources. Data collection techniques used are documentation and interviews. Data analysis techniques used are descriptive. The results of the research show that the internal control of accounts receivable PT. XYZ has not been done effectively. this is seen from the activity of controlling trade receivables in the collection results that often pass from the due date. PT. XYZ do not have internal audits and have not been effective in using accounting methods to the maximum in an effort to minimize bad debt expense.
\end{abstract}

Keyword: Control of Trade Account Receivable, Bad Debt Expense.

\section{PENDAHULUAN}

Perkembangan industri yang semakin pesat mengharuskan setiap perusahaan untuk siap menghadapi persaingan yang sangat ketat untuk mempertahankan kelangsungan usahanya. Untuk dapat bertahan dan menjadi yang terdepan dalam persaingan dalam usaha, perusahaan harus bisa menjalankan segala aktivitas usaha dengan efektif dan efisien sehingga dapat meningkatkan keuntungan yang maksimal. Ada banyak cara yang dapat ditempuh oleh manajemen perusahaan untuk dapat meningkatkan pendapatan dari hasil penjualan, salah satunya penjualan secara kredit untuk dapat meningkatkan profit perusahaan. Piutang usaha adalah pengakuan kepada pihak lain berupa barang, jasa uang serta aset bukan kas yang akan ditagih pada saat jatuh tempo sesuai dengan perjanjian yang telah disepakati (Syakur, 2015). Piutang usaha dapat berupa tagihan yang muncul karena penjualan barang dagangan dan jasa atau penjualan aset lainnya yang dilakukan secara kredit. Perusahaan yang menjalankan 
penjualan secara kredit memerlukan pengelolaan internal yang baik. Salah satunya adalah piutang usaha yang harus dikelola sebaik mungkin agar dapat membantu perusahaan dalam memonitor kegiatan penjualannya. Bagi perusahaan untuk mengetahui apakah sistem pengendalian internal yang berlangsung dalam setiap transaksi piutang usaha sudah termonitor dengan baik atau hanya sekedar formalitas dalam perusahaan. Kondisi ketidakpastian merupakan suatu hal yang wajar jika ada sejumlah piutang usaha yang tidak dapat tertagih pada saat jatuh tempo dan bahkan ada yang benarbenar tidak dapat dibayar oleh pihak yang berhutang, sehingga hutang tersebut dihapus oleh pemilik piutang usaha. Tetapi perusahaan biasanya tidak dapat mengetahui dengan tepat berapa besarnya nilai piutang usaha yang dapat ditagih maupun yang tidak dapat ditagih. Akibat dari adanya piutang usaha yang tidak tertagih ini maka akan sangat berpengaruh pada pendapatan perusahaan, di mana semakin besar biaya yang disisihkan untuk kerugian piutang tak tertagih maka semakin sedikit pendapatan perusahaan yang didapatkan. Penerapan pengendalian internal atas piutang usaha berguna untuk mengukur efektifitas pengelolaan piutang usaha pada perusahaan. Beberapa cara yang telah dilakukan untuk mencegah terjadinya piutang tak tertagih yang telah dilakukan manajemen perusahaan antara lain: mempercepat penerbitan kuitansi, mempercepat pengantaran surat penagihan, pemberian batasan tugas dan tanggung jawab antara sales dan bagian lainnya. Akan tetapi, masalah yang umum dihadapi adalah penagihan piutang usaha yang telah jatuh tempo dan tidak dapat diselesaikan dengan pelunasan atas piutang usaha tersebut. Piutang tak tertagih adalah hak perusahaan untuk menagih sejumlah hutang kepada pelanggan yang belum melakukan pembayaran atas transaksi penjualan secara kredit yang sudah melewati batas akhir jatuh tempo atau transaksi penjualan kredit yang tidak bisa dibayarkan tepat pada waktunya (Wahyuni,2012).

Kerugian pendapatan dan penurunan laba diakui dengan mencatat beban piutang usaha ragu-ragu (beban piutang tak tertagih). PT. XYZ 
Indonesia merupakan salah satu perusahaan swasta yang sangat berkembang dalam bidang penyediaan peralatan mesin pabrik khususnya dari sektor industri. Untuk mendukung kegiatan perusahaan dalam meningkatkan laba PT. XYZ Indonesia banyak melakukan penjualan dengan cara pemberian fasilitas kredit kepada beberapa pelanggannya, penjualan secara kredit dapat mendatangkan keuntungan atau laba yang lebih besar tetapi hal ini tidak terlepas dari adanya risiko kerugian yang harus ditanggung oleh perusahaan apabila pelanggan tidak mampu melunasi piutang usaha yang sudah ada. Perusahaan yang melakukan penjualan secara kredit memerlukan suatu sistem pengendalian internal yang maksimal untuk dapat meminimalkan jumlah piutang usaha yang tidak dapat tertagih. Sistem pengendalian internal dapat dilakukan dengan kebijakan kredit yang bersifat selektif. Analisis terhadap pelanggan sangat diperlukan untuk memastikan kemampuan dalam melunasi piutang usaha. Berikut tabel umur saldo piutang usaha pada PT. XYZ selama tahun 2014 sampai dengan tahun 2018 sebagai berikut:

Tabel 1 Daftar saldo piutang usaha PT. XYZ

\begin{tabular}{cc|cc} 
Tahun & Saldo Piutang Usaha & $\begin{array}{c}\text { Jumlah Piutang } \\
\text { Usaha } \\
\text { Tak Tertagih }\end{array}$ & $\begin{array}{c}\text { Presentase Piutang } \\
\text { Usaha } \\
\text { Tak Tertagih }\end{array}$ \\
\hline 2014 & 5.742 .851 .741 & $755.894 .278,27$ & $13.1 \%$ \\
2015 & 3.195 .687 .785 & $728.435 .281,87$ & $22.8 \%$ \\
2016 & 1.197 .006 .292 & 45.224 .711 & $3.7 \%$ \\
2017 & 2.492 .842 .973 & $338.659 .142,78$ & $13.5 \%$ \\
2018 & 3.197 .431 .747 & $729.734 .898,76$ & $22.8 \%$ \\
\hline
\end{tabular}

Dari data di atas menunjukan bahwa saldo piutang usaha mengalami kenaikan dari tahun 2014 sampai dengan tahun 2016, jumlah piutang tak tertagih mengalami peningkatan dari tahun 2014 sampai dengan tahun 2015 dan mengalami penurunan ditahun 2016 selanjutnya ada kenaikan dari tahun 2017 sampai dengan tahun 2018. Jika dilihat dari data di atas, adanya peningkatan piutang tak tertagih dari kurangnya pengendalian internal yang kurang baik. Ada beberapa cara untuk 
meminimalkan piutang tak tertagih seperti: mengamankan sumber daya terhadap kemungkinan kerugian akibat pelepasan piutang usaha, penyalahgunaan kesalahan pengelolaan, kekeliruan, kecurangan serta membuat data keuangan dan pengungkapan data yang wajar pada pelaporan piutang usaha. Agar terlaksananya pengendalian internal dan administrasi yang lebih baik, diperlukan sistem pengendalian yang dirancang secara efektif guna untuk pelaksanaan pengumpulan piutang tak tertagih dapat berjalan dengan baik dan memadai. Jenis piutang usaha yang ada pada PT XYZ adalah piutang usaha, piutang usaha karyawan dan piutang usaha lainlain. Metode umur piutang usaha dikelompokan berdasarkan pada karakteristik umur yang berarti adanya pengelompokan piutang usaha ke dalam katagori yang berdasarkan tanggal jatuh tempo piutang usaha. Karakteristik umur piutang usaha dapat dikelompokan menjadi: belum jatuh tempo, telah jatuh tempo 1-30 hari, telah jatuh tempo 31-60 hari, telah jatuh tempo 61-90, telah jatuh tempo 91-120 hari dan jatuh tempo di atas 121 hari.
Lamanya umur piutang usaha yang telah jatuh tempo merupakan lamanya hari mulai saat piutang usaha tersebut jatuh tempo hingga laporan umur piutang usaha (aging account receivable). Piutang usaha dan piutang usaha lain-lain diharapkan dapat tertagih dalam satu tahun atau siklus usaha normal dikelompokan sebagai aset lancar. Seluruh piutang usaha digolongkan sebagai aset lancar tanpa memandang waktu tertagihnya piutang usaha tersebut. Dengan demikian, jumlah piutang usaha yang jangka waktu penagihannya lebih dari satu tahun atau siklus usaha normal harus diungkapkan dalam catatan atau laporan keuangan. Berdasarkan latar belakang permasalahan di atas, peneliti akan melakukan penelitian tentang sistem pengolahan piutang usaha pada PT. XYZ dan membahas dalam skripsi yang berjudul: analisis pengendalian internal piutang usaha untuk meminimalkan piutang tak tertagih pada PT. XYZ. Berdasarkan uraian latar belakang masalah tersebut maka peneliti merumuskan permasalahan sebagai berikut: apakah pengendalian internal piutang usaha yang 
diterapkan pada PT. XYZ sudah

efektif dan efisien dalam meminimalkan piutang tak tertagih. Berdasarkan latar belakang dan rumusan masalah di atas, maka batasan masalah penelitian ini hanya membahas tentang pengendalian internal piutang usaha yang berhubungan dengan risiko piutang tak tertagih dengan cara:

1. Menganalisis pengendalian

\section{TELAAH LITERATUR}

Piutang Usaha

Piutang usaha adalah penjualan kepada pelanggan yang dilakukan secara kredit yang tidak memerlukan cacatan secara khusus atau formulir khusus yang ditandatangai sebagai bukti atas kewajiban yang di buat antara penjual dengan pembeli. (Lukman Syamsuddin, 2011). Piutang usaha adalah klaim kepada pihak lain atas penjualan barang, jasa, uang serta aset bukan kas yang ditagih sesuai dengan tanggal perjanjian penagihan (Syakur, 2015). Piutang usaha adalah hak memperoleh hasil penjualan kredit yang dilakukan pada masa lalu, ditagih pada masa yang akan datang sesuai dengan tanggal jatuh tempo piutang usaha yang telah dijalankan PT. XYZ yang telah berjalan sejak tahun 2014.

2. Menganalisis risiko piutang tak tertagih dari tahun 2014 sampai dengan 2018 pada PT. XYZ dengan umur piutang usaha yang lebih dari 121 hari.

penagihan. (Rudianto, 2012). Dari definisi tersebut, piutang usaha merupakan aset lancar atau kekayaan perusahaan yang timbul karena adanya penjualan secara kredit. Piutang usaha merupakan hal yang sangat penting bagi perusahaan dalam mempertahankan persaingan bisnis sekarang ini. Piutang usaha merupakan hak untuk menagih sejumlah uang penjual kepada pembeli yang timbul karena adanya suatu transaksi.

Untuk tujuan pelaporan keuangan, piutang usaha diklasifikasikan menjadi dua yaitu piutang usaha jangka panjang yang artinya tidak dapat tertagih dalam periode tertentu dan piutang usaha jangka pendek 
adalah dapat tertagih dalam satu periode tertentu.

\section{Piutang Tak Tertagih}

Piutang tak tertagih muncul karena adanya pelanggan yang tidak mampu membayar hutangnya kepada perusahaan, hal ini dikarenakan adanya penurunan omset penjualan sebagai akibat dari lemahnya perekonomian dan kebangkrutan yang dialami oleh pelanggan (Hery, 2013). Piutang tak tertagih adalah hak perusahaan untuk menagih sejumlah hutang kepada pelanggan yang belum melakukan pembayaran atas transaksi penjualan secara kredit yang sudah melewati batas akhir jatuh tempo atau transaksi penjualan kredit yang tidak bisa dibayarkan tepat pada waktunya (Wahyuni, 2012). Piutang tak tertagih adalah berkurangnya pendapatan yang diakibatkan dari piutang usaha yang tidak terbayarkan oleh pelanggan. Hal ini memerlukan pencatatan ayat jurnal yang tepat dalam akun keuangan perusahaan, penurunan pendapatan yang berdampak dari piutang usaha yang tidak dapat ditagih mengakibatkan perubahan laba dan ekuitas pemegang saham
(Ahmed, 2015). Kerugian pendapatan dan penurunan laba diakui dengan mencatat beban piutang usaha ragu-ragu (atau beban kerugian tak tertagih). Beban piutang tak tertagih merupakan biaya bagi penjual yang memberikan kredit. Dari definisi tersebut, piutang tak tertagih adalah kerugian bagi perusahaan akibat sejumlah piutang usaha yang tidak dapat dilunasi oleh pihak pelanggan yang dikarenakan pelanggan yang tidak diketahui keberadaannya, tidak mau membayar hutangnya, tidak mampu membayar atau dinyatakan bangkrut.

Faktor-Faktor yang Mempengaruhi Besarnya Investasi Dalam Piutang usaha

Faktor-faktor yang mempengaruhi besarnya investasi dalam piutang usaha adalah sebagai berikut:

1. Volume penjualan kredit.

Semakin besar penjualan kredit dari keseluruhan penjualan kredit akan memperbesar jumlah piutang usaha pada perusahaan dan mengakibatkan risiko adanya piutang tak tertaih dan sebaliknya semakin kecil penjualan kredit dari keseluruhan piutang usaha akan memperkecil piutang usaha. 
2. Syarat pembayaran bagi penjualan kredit.

Semakin panjang batas waktu pembayaran kredit yang diberikan oleh perusahaan kepada pelanggan, berarti semakin besar jumlah piutang usahanya dan apabila semakin pendek batas waktu pembayaran kredit berarti semakin kecil besarnya jumlah piutang usaha.

3. Ketentuan dengan batas volume penjualan kredit.

Apabila batas maksimal volume penjualan kredit ditetapkan dalam jumlah yang relatif besar maka besarnya piutang usaha juga semakin besar.

4. Kebijakan membayar para pelanggan.

Apabila kebiasaan keterlambatan membayar para pelanggan dari penjualan kredit melebihi waktu yang dipersyaratkan, maka besarnya jumlah piutang tak tertagih semakin besar.

5. Kegiatan penagihan piutang usaha dari pihak perusahaan.

Apabila kegiatan penagihan piutang usaha perusahaan bersifat lancar dan pelanggan melunasi piutang usahanya tepat waktu, maka besarnya jumlah piutang usaha bersifat relatif kecil, tetapi apabila kegiatan penagihan piutang usaha bersifat macet maka besarnya jumlah piutang usaha relatif besar begitu pula dengan risiko piutang tak tertagih.

\section{Perputaran Piutang usaha}

Perputaran piutang usaha yang dimiliki oleh perusahaan mempunyai hubungan yang sangat erat dengan tingkat penjualan kredit. Timbulnya piutang usaha disebabkan oleh penjualan secara kredit dan dari hasil penjualan secara kredit neto dibagi dengan piutang usaha rata-rata merupakan perputaran piutang usaha. Nilai dari perputaran piutang usaha tergantung dari syarat pembayaran piutang usaha yang ditetapkan oleh perusahaan. Semakin lama syarat pembayaran yang ditetapkan maka semakin lama juga modal yang akan terkait di dalam piutang usaha tersebut. Perputaran piutang usaha merupakan standar dalam menentukan tujuan dari pengelolaan piutang usaha. Semakin cepat perputaran piutang usaha menunjukan dampak baik bagi perusahaan dalam mengelola piutang usahanya (Sutrisno, 2010). Tingkat 
perputaran piutang usaha dapat diketahui dengan cara membagi penjualan kredit dengan jumlah ratarata piutang usaha, tidak ada standar yang pasti berapa angka yang pas untuk tiap hasil perputaran piutang usaha, rata-rata piutang usaha dan rata-rata jangka waktu penagihan (Kasmir, 2014). Untuk memberikan penilaian perputaran piutang usaha yang baik pada satu perusahaan dapat di lakukan dengan cara menganalisis dan menghitung tingkat perputaran piutang dan menetapkan batas maksimal perputaran piutang tak tertagih. Tidak ada standar khusus dalam menetukan hasil dari perputaran piutang usaha dari tiaptiap perusahaan. Likuiditas dari piutang usaha yang dapat diketahui melalui analisis rasio perputaran piuang usaha (receivable turnover ratio), perputaran piutang usaha menunjukan beberapa kali piutang usaha perusahaan berputar dalam satu tahun. Perputaran piutang usaha dapat dihitung dengan rumus:

$$
\text { Perputaran piutang usaha }=\frac{\text { penjualan kredit bersih }}{\text { saldo rata }- \text { rata piutang usaha }}
$$

Untuk menghitung rata-rata piutang usaha adalah:

$$
\frac{\text { saldo awal piutang usaha }+ \text { saldo akhir piutang usaha }}{2}
$$

Semakin besar hasil perhitungan dari perputaran piutang usaha berarti semakin cepat pengembalian piutang usaha tersebut dibayarakan, perputaran piutang usaha menunjukan beberapa penjabaran, yaitu jumlah modal yang diinvestasikan dalam bentuk piutang usaha belum berubah menjadi bentuk tunai atau kas. Semakin cepat perputaran piutang usaha maka semakin sedikit pula dana yang diinvestasikan dalam piutang usaha. Bila perputaran piutang usaha lambat dikarenakan kinerja bagian penagihan kurang maksimal atau pelanggan mengulur waktu pembayaran dari tanggal jatuh tempo. Jika perputaran piutang usaha menunjukan angka kredit yang 
melebihi dari ketenuan yang penagihan menunjukan pada rata-rata ditetapkan oleh manajemen waktu yang diperlukan perusahaan perusahaan, kemungkinan masalah untuk mengumpulkan piutang usaha terletak pada pelanggan yang tidak mampu atau tidak mau membayar hutangnya. Rata-rata jangka waktu dalam suatu periode tertentu. Ratarata jangka waktu penagihan dapat dihitung dengan rumus:

$$
\text { Rata }- \text { rata jangka waktu penagihan }=\frac{360 \text { hari (1tahun) }}{\text { perputaran piutang usaha }}
$$

Terdapat lima komponen
pengendalian internal menurut
COSO (Committee of sponsoring
organizations of the treadway
commission) yaitu:

\section{Lingkungan Pengendalian}

Komponen ini meliputi prilaku manajemen disemua bagian operasional perusahaan secara umum dan konsep pengendalian secara khusus. Hal ini mencakup etika, kompetensi serta integritas dan kepentingan terhadap kesejahteraan organisasi. Kode etik adalah upaya yang dilakukan oleh perusahaan dalam mendorong kegiatan dari pengendalian internal perusahaan. Perbedaan dalam kegiatan perusahaan harus dinyatakan secara jelas kepada karyawan mengenai kode etik yang mereka jalankan dan dibutuhkan dukungan dari manajemen agar kode etik dapat berjalan dengan baik. Kompetensi adalah kemapuan yang dimiliki oleh pegawai sebagai modal dalam melaksanakan tugas dan tanggung jawab serta kemampuan dalam mencapai suatu tujuan yang sudah ditentukan oleh manajemen perusahaan. Integritas adalah suatu sikap dalam menyatakan keinginan atau kehendak, kejujuran dan keiklasan serta perbuatan antara orang-orang yang memiliki suatu tujuan yang sama.

Penentuan risiko

Penetuan risiko merupakan hal yang sangat penting bagi manajemen, penentuan risiko mencakup ke semua aspek organisasi yang ada diperusahaan dan merupakan tanggung jawab yang tidak 
terpisahkan. Terdapat banyak hambatan atau risiko yang datang dari dalam maupun dari luar perusahaan. Risiko yang sering muncul dalam penjualan perusahaan adalah risiko kredit, di mana pelanggan tidak mampu memenuhi kewajibannya dalam membayar hutang atas pembelian barang atau jasa.

\section{Aktivitas Pengendalian}

Aktivitas ini meliputi persetujuan, tanggung jawab dan kewenangan, pemisahan tugas, pendokumentasian, rekonsiliasi dan lain sebagainya dari manajemen perusahaan dan seluruh karyawan. Aktivitas ini harus dievaluasi risikonya untuk organisasi secara keseluruhan. Menurut (Mulyadi, 2014), Prosedur pemisahan tugas dalam rangka memenuhi aktivitas pengendalian harus memenuhi aktivitas pengendalian antara lain :

Informasi dan Komunikasi

Komponen ini merupakan kegiatan penting dari proses operasional manajemen perusahaan. Informasi komuniasi tentang operasional pengendali internal memberikan pendapatan yang dapat digunakan manajemen untuk mengevaluasi efektivitas pengendalian internal perusahaan dan untuk mengelola seluruh kegiatan yang dilakukan karyawan. Komunikasi bisa dilakukan secara langsung melalui pengawasan dan pemantauan terhadap kegiatan yang ada diperusahaan dan perbaikan atas informasi yang diberikan pada komunikasi informasi untuk manajemen pengendalian. Komunikasi adalah proses penyampaian informasi yang disampaikan kepada pihak lain untuk memberikan pengertian atau pesan secara jelas dan terperinci secara khusus (Saefullah dan Ernie, 2010).

Pengawasan dan Pemantauan Faktor-faktor yang mempengaruhi investasi dalam piutang usaha adalah sebagai berikut:

1. Volume penjualan kredit.

Semakin besar kegiatan penjualan kredit dari keseluruhan penjualan yang ada diperusahaan, maka semakin besar jumlah investasi dalam piutang usaha dan dapat juga memperbesar 
pendapatan perusahaan.

mendapatkan fasilitas kredit.

Semakin besarnya jumlah

4. Kebijakan

dalam

piutang usaha berarti semakin

mengumpulkan

piutang

besar pula risiko piutang tak

tertagih.

usaha.

Perusahaan

yang

2. Syarat pembayaran penjualan kredit.

Dalam penjualan kredit, tiap perusahaan memiliki syarat pembayaran yang berbedabeda dari perusahaan lain.

Apabila

perusahaan

menetapkan

syarat

pembayaran atas penjualan

kredit dan dijalankan dengan sangat disiplin berarti

perusahaan

lebih

mengutamakan keselamatan

kredit dari pada pertimbangan

pendapatan.

3. Ketentuan

tentang

pembatasan kredit.

Makin tinggi batas kredit

limit yang diberikan kepada

pelanggan berarti semakin besar juga dana yang diinvestasikan dalam piutang usaha dan semakin besar juga risiko piutang tak tertagih yang akan timbul. Perusahaan harus lebih selektif dalam menentukan pelanggan yang menjalankan kebijakan secara aktif dalam mengumpulkan piutang usaha akan mempunyai pengeluaran uang yang cukup besar untuk membiayai aktivitas pengumpulan piutang usaha tersebut dibandingkan dengan perusahaan lain yang menjalankan kebijakan secara pasif. Hal ini dapat berdampak pada ketertiban dalam kemampuan pelanggan melunasi hutangnya kepada perusahaan.

5. Kebiasaan membayar dari para pelanggan.

Ada sebagian pelanggan yang mempunyai kebiasan untuk membayar dengan menggunakan kesempatan mendapatkan cash diskon dan ada sebagian lain yang tidak menggunakan kesempatan tersebut. Kebiasaan beberapa pelanggan yang membayar dalam cash diskon memiliki 


$\begin{array}{lcl}\text { dampak besar bagi } & \text { dapat mengurangi pendapatan } \\ \text { perusahaan, hal tersebut } & \text { perusahaan. }\end{array}$

\section{METODOLOGI PENELITIAN}

Metode pendekatan yang gunakan dalam penelitian ini adalah metode deskriptif, yaitu penelitian yang menguraikan sifat-sifat dan keadaan sebenarnya dari suatu objek penelitian. Pengertian metode deskriptif adalah metode yang digunakan untuk menggambarkan atau menganalisis suatu hasil penelitian tetapi tidak digunakan untuk membuat kesimpulan yang lebih luas. Deskriptif juga mengumpulkan fakta dan menguraikannya secara menyeluruh dan teliti sesuai dengan persoalan yang akan dipecahkan. Penelitian ini membahas sistem pengendalian internal piutang usaha dan kemampuan dalam meminimalkan nilai piutang tak tertagih pada PT. XYZ. Data yang gunakan dalam penelitian ini adalah data primer. Data primer merupakan data yang diperoleh secara langsung dari sumber pertama yaitu pada PT. XYZ. Data primer yang dikumpulkan dari tahun 2014-2018. Data sekunder merupakan data pendukung yang bersifat memperkuat hasil analisis, data ini merupakan data yang sudah disusun oleh perusahaan, berupa sejarah perkembangan perusahaan, deskripsi jabatan dan struktur organisasi. Jenis data yang digunakan dalam penelitian ini adalah data kualitatif. Data kualitatif adalah data yang bukan merupakan bilangan, tetapi berupa daftar piutang usaha, rekapitulasi umur piutang usaha dan jawaban wawancara. Sumber data yang digunakan dalam penelitian ini adalah Data yang belum diolah yang diperoleh langsung dari responden selaku objek penelitian secara dengan staf finance account receivable PT. XYZ. Data yang diolah dan diperoleh dari sumber yang sudah terdokumentasi di perusahaan seperti sejarah singkat perusahaan, struktur organisasi perusahaan. Dalam penelitian analisis pengendalian internal piutang usaha untuk meminimalkan piutang tak tertagih pada PT. XYZ, peneliti hanya membahas tentang piutang usaha dan piutang tak tertagih yang timbul atas 
transaksi penjualan kredit. Peneliti juga membahas tentang sistem pengendalian internal yang ada pada PT. XYZ dengan membandingkan teori COSO terhadap unsur pengendalian yang ada di perusahaan tempat penelitian. Hasil analisis ini digunakan untuk membahas dan menerangkan hasil penelitian dengan menggunakan angka yang didapat dari piutang usaha dan keterangan mengenai angka yang peroleh dari hasil perhitungan dalam penelitian. Penelitian ini menggunakan metode deskriptif yaitu dengan menganalisis data dengan cara menentukan, mengumpulkan, mengklarifikasi, serta menganalisis hasil perhitungan dari piutang usaha sehingga menghasilkan gambaran yang jelas mengenai pengendalian piutang

\section{PEMBAHASAN}

Prosedur pencatatan atas piutang usaha PT. XYZ dilakukan setiap hari pada saat adanya transaksi penjualan secara kredit. Pencatatan piutang usaha diakui saat surat jalan atas transaksi tersebut sudah tercetak oleh gudang. Sistem pencatatan yang berlaku di PT. XYZ adalah catatan perhari. Ada beberapa prosedur yang usaha terhadap risiko piutang tak tertagih. Apabila perusahaan menjalankan pengendalian piutang usaha dengan baik, maka dapat meningkatkan tingkat likuiditas perusahaan dan apabila perusahaan tidak menjalankan pengendalian piutang usaha dengan baik maka tingkat likuiditas perusahaan dapat mengalami penurunan. Tidak ada standar khusus yang ditetapkan dalam hasil perhitungan perputaran piutang usaha, apabila hasil yang diperoleh dari perhitungan perputaran piutang mengalami kenaiakan atau penurunan maka pengendalian piutang usaha yang ada di perusahaan tidak diberlakukan dengan baik dan perlu dilakukan perbaikan terhadap manajemen pengendalian internal piutang usaha.

dijalankan selama terjadinya piutang usaha seperti pernyataan piutang usaha adalah laporan piutang usaha yang menyajikan jumlah kewajiban pelanggan pada tanggal tertentu atau sebelum jatuh tempo pembayaran dan dalam pernyataan piutang usaha tertentu disertai dengan rinciannya. Pernyataan piutang usaha dapat berbentuk pernyataan saldo akhir 
bulan. Pernyataan ini memberikan informasi kepada pelanggan untuk dasar rekonsiliasi dengan catatannya, jika saldo yang tercantum dalam pernyataan piutang usaha berbeda dengan saldo yang tercantum dalam catatannya. Penyataan piutang usaha ini berisi saldo kewajiban pelanggan pada awal bulan. Mutasi debit dan kredit selama sebulan beserta penjelasan rinci setiap transaksi. Saldo kewajiban pelanggan pada akhir bulan, prosedur pembuatan pernyataan piutang usaha dilakukan pada awal bulan, menyusun laporan piutang usaha yang masih belum ada pelunasan. Mencatat saldo jumlah piutang usaha dari hasil menyusun laporan piuang usaha yang sudah jatuh tempo. Semua transaksi pendebitan dan perkreditan ke rekening pelanggan tersebut dicatat dalam kartu piutang usaha masingmasing pelanggan. Pada akhir bulan, bagian penagihan piutang usaha mengirimkan hasil laporan piutang usaha yang sudah atau mendekati tanggal jatuh tempo kepada pelanggan yang bersangkutan. Pada awal bulan berikutnya, menyusun laporan piutang usaha yang masih belum ada pelunasan, data diambil dari data piutang usaha sebelumnya. Pernyataan saldo berjalan dengan rekening konvensional, perbedaan diantara pernyataan satuan dengan pernyataan saldo berjalan dengan rekening konvensional adalah terletak pada cara posting dan isi catatan piutang usahanya. Pada awal bulan, staf administrasi account receivable menyusun laporan pencatatan piutang usaha dengan cara semua transaksi debit dan kredit yang masuk ke rekening pelanggan dicatat dalam laporan pernyataan piutang usaha dan kartu piutang usaha. Pada akhir bulan, informasi mengenai pernyataan piutang usaha dikirim kepada pelanggan yang bersangkutan. Pada awal bulan berikutnya laporan pernyataan piutang usaha hanya berisi mutasi tiap bulannya. Pernyataan piutang usaha berisi daftar faktur yang belum dilunasi oleh pelanggannya pada tanggal tertentu disertai dengan tanggal faktur dan jumlah rupiahnya. Penggunaan bentuk pernyataan piutang usaha ini dimungkinkan jika pelanggan diharuskan membayar jumlah piutang usaha yang tercantum dalam faktur dan yang mendekati tanggal jatuh tempo. Piutang usaha 
yang dijalankan PT. XYZ sudah dilakukan dengan cukup baik. Pencatatan piutang usaha dengan mengunakan komputerisasi program SAP dan pencatatan secara manual dengan buku yang dicatat oleh seorang staf administrasi account receivable. Laporan hasil piutang usaha yang setiap hari diinput dalam program SAP dilaporkan minimal 1 (satu) minggu sekali kepada supervisor account receivable untuk menghindari adanya kecurangan atau penyelewengan baik data maupun dana yang diterima dari hasil penagihan piutang usaha, laporan piutang usaha bulanan dilaporkan kepada manager accounting. Berdasarkan hasil penelitian pada PT. XYZ, sistem pengendalian internal atas piutang usaha dalam menunjang efektivitas pengelolaan piutang tak tertagih dengan cara membandingkan antara hasil penelitian yang diperoleh dengan landasan teori yang ada. Pengendalian internal PT. XYZ terhadap piutang usaha dapat dijelaskan berdasarkan faktor-faktor pengendalian dibawah ini:
Kode etik

PT. XYZ, mengkoordinasiakan manajemen operasional dengan menciptakan hubungan bisnis yang baik kepada semua pihak yang berhubungan dengan perusahaan terhadap kepuasaan pelayanan penjualan kepada para pelanggan sangat perlu diperhatikan. PT. XYZ mengutarakan bahwa apabila ada kebutuhan dan keinginan dari para pembeli terhadap penjualan kredit, perusahaan akan secepat mungkin melayani pelanggan agar tidak terjadi keterlambatan dalam proses pejualan kredit. Karyawan ditekankan untuk memiliki rasa hormat kepada pelanggan baik itu pelanggan dengan pembelian kredit maupun tunai.

\section{Kompetensi}

Struktur organisasi secara fungsional terdiri dari direktur utama, manajer kepegawaian, manajer accounting keuangan dan administrasi, manajer produksi dan gudang serta seluruh staf administrasi dari masing-masing bagian. Penyusunan struktur organisasi disusun berdasarkan fungsi dari masing-masing bagian yang terlibat dalam kegiatan yang 
berjalan pada PT. XYZ terlihat sudah cukup jelas pembagian tugas, tanggung jawab dan wewenang dari setiap fungsional yang ada diperusahaan, sehingga pengendalian internal perusahaan dapat dilakukan dengan cukup baik.

Integritas

PT. XYZ masih menggunakan prinsip kekeluargaan dalam memberikan fasilitas kredit kepada beberapa pelanggan yang memiliki hubungan keluarga dengan direktur utama. Perusahaan sangat menjunjung tinggi nilai kejujuran bagi seluruh karyawannya, hal ini benar terrealisasi dengan pemecatan beberapa karyawan khususnya pada bagian penjualan yang diketahui melakukan tindak kebohongan dengan membuat kwitansi palsu atas pembelian suatu barang.

Penilaian risiko atas piutang usaha

Berdasarkan hasil penelitian pada PT. XYZ, penilaian risiko atas piutang usaha dilakukan untuk menghindari risiko terjadinya piutang usaha yang terlewat dalam pencatatan atau piutang tak tertagih. Untuk membantu mendapatkan saldo dalam konfirmasi saldo piutang usaha pelanggan, maka langkah yang diambil perusahaan dengan menggunakan buku pembantu piutang usaha yang di update setiap harinya.

Aktivitas pengendalian atas piutang usaha.

Aktivitas pengendalian atas piutang usaha meliputi pemisahan tugas dan pemeriksaan independen atau verifikasi internal yang dibuat oleh perusahaan. Hal ini berguna untuk memberikan kemungkinan yang memadai bahwa sistem pengendalian atas piutang usaha yang ditetapkan telah dilaksanakan dalam beberapa kategori seperti diuraikan berikut:

Pemisahan tugas

Pemisahan tugas dan fungsi dalam struktur organisasi sudah jelas namun dari pada PT. XYZ terdapat perangkapan fungsi dan peran oleh beberapa karyawan. Seperti bagian accounting dan administrasi seharusnya dipisahkan dengan bagian penagihan dan pencatatam piutang usaha. Hal ini dikarenakan divisi accounting dan administrasi masih dipegang langsung oleh satu 
orang manajer accounting dan administrasi.

Pengendalian internal

Berdasarkan hasil penelitian pada PT. XYZ, perusahaan tidak mempunyai pengendalian internal dan proses pengendalian internal dilakukan oleh audit internal kantor akuntan publik (KAP). Di mana audit internal dilakukan kepada divisi keuangan yang dilakukan satu kali dalam setahun.

Informasi dan komunikasi atas piutang usaha

Berdasarkan hasil penelitian pada PT. XYZ, sistem informasi dan komunikasi yang dilakukan PT. XYZ sudah cukup baik. Hal ini dikarenakan adanya komunikasi antara direktur utama sampai kepada karyawan. Perusahaan telah mencatat piutang usaha secara komputerisasi dan pencatatan secara manual, sehingga staf administrasi account receivable dapat memberikan informasi saldo piutang usaha secara terperinci. Hal ini membantu perusahaan untuk menganalisis umur piutang usaha pelanggan, sehingga untuk pelanggan yang tidak tepat dalam pelunasan hutangnya, maka perusahaan terus melakukan follow up dan pemantauan langsung kepada pelanggan. Jika terjadi perubahan peraturan dalam perusahaan dengan cepat dikomunikasikan kepada pegawai. Pengendalian terhadap piutang usaha biasanya dianggap sebagai bagian dari siklus pendapatan dan penerimaan kas. Dalam hal ini PT. XYZ membuat kebijaksanaan terhadap sistem piutang usaha mulai dari pemberiaan fasilitas kredit sampai dengan batas umur piutang usaha.

Pengawasan dan Pemantauan Piutang usaha.

Pengawasan berhubungan dengan penilaian mutu pengendalian internal secara berkelanjutan oleh manajemen perusahaan untuk menetukan bahwa pengendalian tersebut telah dijalankan seperti yang diharapkan. Manajemen PT. XYZ telah menggariskan tugas dan tanggung jawab kepada masing-masing bagian secara jelas. Kelancaran piutang usaha menjadi tanggung jawab bagian staff account receivable. Pengawasan pada PT. XYZ pada piutang usaha masih belum baik, 
sehingga menyebabkan adanya peningkatan piutang tak tertagih. PT. XYZ masih belum menjalankan usahanya secara profesional, masih ada beberapa pelanggan yang menjadi keluarga dari direktur utama, hal ini dapat mengakibatkan terlambatnya proses pembayaran. Perusahaan juga tidak melakukan pemeriksaan secara mendadak kepada bagian keuangan, hal ini dapat memicu karyawan melakukan manipulasi data keuangan atau piutang usaha. Dilakukan rotasi pada bagian-bagian tertentu dalam perusahaan agar terhidar dari kasus penyelewengan hasil penagihan piutang usaha perusahaan.

Dalam proses penagihan atas penjualan kredit yang dilakukan PT.XYZ, ada beberapa tahapan dan bagian yang ikut terlibat dalam proses penagihan penjualan kredit. Proses penagihan piutang usaha yang dijalankan PT. XYZ dimulai dari melakukan pengumpulan dokumen untuk proses penagihan kepada pelanggan atas penjualan secara kredit adalah sebagai berikut

Faktur merupakan suatu dokumen perhitungan penjualan kredit yang diberikan oleh penjual kepada pembeli atau pelanggan. Faktur diberikan kepada pelanggan bersamaan dengan penyerahan atau pengiriman barang. Di dalam surat ini berisi berbagai keterangan mengenai pemesan seperti nama, alamat, dan nomor pesanan, barang seperti jumlah, jenis, model, dll biaya-biaya, harga dan keterangan lain yang berkaitan dengan data penjualan. Penerbitan faktur penjualan PT. XYZ dengan menggunakan sistem SAP yang dioperasionalkan oleh administrasi sales. Faktur dicetak pada saat adanya pencatatan transaksi penjualan dan dicetak dengan menggunakan kertas komputer atau continuous form yang terdiri dari lima warna, masing-masing warna memiliki fungsi untuk beberapa bagian yang ada di perusahaan. 


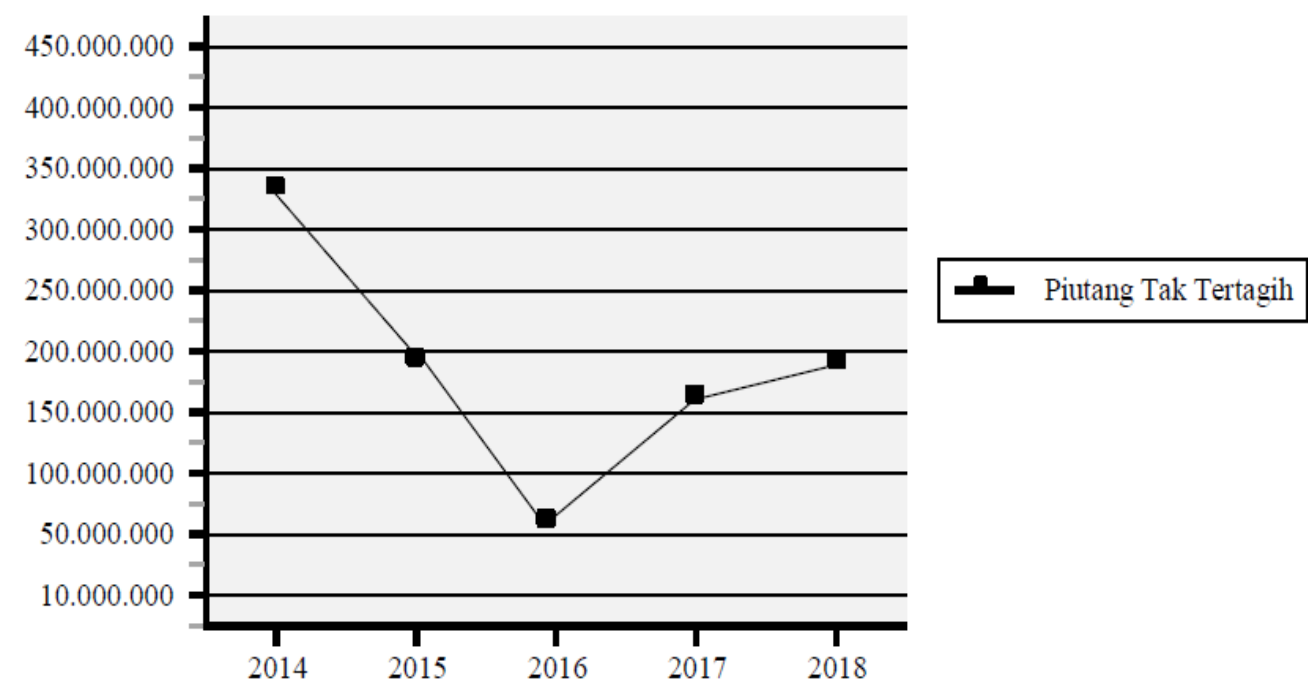

Berdasarkan rekapitulasi umur 3.115.697.785,87 dan ada estimasi piutang usaha terlihat bahwa pada tahun 2014 sampai dengan tahun 2016 piutang tak tertagih mengalami penurunan yang cukup signifikan dan di tahun 2017 sampai dengan tahun 2018 mengalami kenaikan yang cukup tinggi pada PT. XYZ. Data perhitungaan grafik diambil berdasarkan perhitungan estimasi piutang tak tertagih pertahun. Peningkatan saldo piutang tak tertagih pada tahun 2014 sampai dengan tahun 2018 adalah sebagai berikut: Pada tahun 2014 saldo piutang usaha sebesar Rp 5.742.851.741,74 dan estimasi saldo piutang tak tertagihnya pada tahun 2014 sebesar Rp. 330.541.413,47. Pada tahun 2016 saldo piutang usaha menurun $54,25 \% \%$ yaitu sebesar Rp. saldo piutang tak tertagih adalah sebesar Rp 197.559.793,67 hal ini dikarenakan penjualan kredit PT. XYZ mengalami penurunan. Pada tahun 2017 saldo piutang usaha menurun $38,39 \%$ yaitu sebesar Rp. 1.196.364.354 dan estimasi saldo piutang tak tertagih adalah sebesar Rp. 68.583.010,7 hal ini karenakan penjualan kredit PT. XYZ mengalami penurunan. Pada tahun 2018 saldo piutang usaha meningkat $208 \%$ yaitu sebesar Rp. 2.492.842.973,47 dan saldo piutang usaha tertagih adalah sebesar Rp. 152.423.288,76 hal ini dikarenakan penjualan kredit PT. XYZ mengalami kenaikan dan manajemen perusahaan belum mampu meminimalkan saldo piutang tak 
tertagih. Pada tahun 2018 saldo piutang usaha meningkat $30.1 \%$ yaitu sebesar Rp. 3.197.341.747,01 dan pada saldo piutang tak tertagih adalah sebesar Rp. 199.486.671,99 hal ini dikarenakan penjualan kredit PT. XYZ mengalami kenaikan dan manajemen perusahaan belum mampu meminimalkan saldo piutang tak tertagih. Metode umur piutang usaha dikelompokkan berdasarkan pada masing-masing karakteristik umur yang berarti adanya pengelompokan piutang usaha ke dalam kategori yang berdasarkan atau tanggal jatuh tempo piutang usaha. Karakteristik umur piutang usaha disini dapat diklasifikasikan menjadi: belum jatuh tempo, telah jatuh tempo 1-30 hari, telah jatuh tempo 31-90 hari, telah jatuh tempo 91-20 hari, telah jatuh tempo lebih dari 121 hari. Lamanya umur piutang usaha yang telah jatuh tempo merupakan lamanya hari mulai saat piutang usaha tersebut jatuh tempo hingga menjadi laporan umur piutang usaha (aging schedule). Berdasarkan umur piutang usaha yang sudah lama beredar (jatuh tempo) sangat kecil kemungkinannya untuk dapat ditagih (Hery, 2016). Karena jika terlalu besar jumlah saldo piutang tak tertagih ataupun jumlah saldo piutang usaha tidak efektifnya pengendalian terhadap menajer yang memutuskan kredit atau tidak efektifnya bagian piutang usaha yang pada akhirnya menimbulkan kerugian bagi perusahaan. Piutang usaha sebaiknya diharapkan dapat tertagih dalam satu tahun atau siklus usaha normal diklasifikasikan sebagai aset lancar. Seluruh piutang usaha digolongkan sebagai aset lancar karenanya tanpa memandang jangka waktu tertagihnya. Dengan demikian dari hasil analisis yang di lakukan oleh penulis maka, jumlah piutang usaha yang jangka waktu penagihannya lebih satu tahun atau siklus usaha normal harus diungkapkan dalam catatan atau laporan keuangan. Dalam meminimalkan piutang tak tertagih di mana yang terjadi pada PT. XYZ pihak manajemen perusahaan harus mempunyai beberapa metode dalam mengendalikan piutang tak tertagih yang terjadi pada perusahaan. 
Adapun hasil perhitungan dari perputaran piutang usaha adalah sebagai berikut:

Tahun 2014

$$
\text { Perputaran piutang usaha }=\frac{5.742 .851 .741}{3.234 .324 .159}=1,77
$$

Tahun 2015

$$
\text { Perputaran piutang usaha }=\frac{3 \cdot 195 \cdot 687.785}{2 \cdot 141.404 .810}=1,49
$$

Tahun 2016

$$
\text { Perputaran piutang usaha }=\frac{1 \cdot 197.006 .292}{1.093 .834 .753}=1,09
$$

Tahun 2017

$$
\text { Perputaran piutang usaha }=\frac{2.493842 .973}{1.269 .164 .606}=1,96
$$

Tahun 2018

$$
\text { Perputaran piutang usaha }=\frac{3 \cdot 197.341 .747}{1.807 .556 .473}=1,76
$$

Tabel 2 Hasil perhitungan receivable turn over (RTO)

\begin{tabular}{ccccc} 
Tahun & $\begin{array}{c}\text { Penjualan kredit } \\
(\mathbf{R p})\end{array}$ & $\begin{array}{c}\text { Rata-Rata } \\
\text { Piutang usaha } \\
(\text { Rp) }\end{array}$ & $\begin{array}{c}\text { RTO } \\
(\text { Kali) }\end{array}$ & $\begin{array}{c}\text { Perubahan } \\
\text { RTO }\end{array}$ \\
2014 & 5.742 .851 .741 & 3.234 .324 .159 & 1,77 & - \\
2015 & 3.195 .687 .785 & 2.141 .404 .810 & 1,49 & 0,28 \\
2016 & 1.197 .006 .292 & 1.093 .834 .753 & 1,09 & 0,40 \\
2017 & 2.492 .842 .973 & 1.269 .164 .606 & 1,96 & 0,51 \\
2018 & 3.197 .431 .747 & 1.807 .556 .473 & 1,76 & 0,20 \\
\hline
\end{tabular}

Dari data di atas menunjukan bahwa kinerja RTO mengalami penurunan dari tahun 2014 sampai dengan tahun 2018. Hal ini ditunjukan pada hasil RTO tahun 2014 sebesar 1,77 kali. Pada tahun 2015 terjadi penurunan RTO yaitu 1.49 kali atau menurun 0.28 dari tahun sebelumnya. Pada tahun berikutnya, yaitu ditahun 2016 terjadi penurunan RTO sebesar 1.09 atau menurun 0.40 dari tahun sebelumnya. pada tahun berikutnya, yaitu ditahun 2017 terjadi kenaikan RTO sebesar 1.96 kali atau naik 0.51 dari tahun sebelumnya. Dan ditahun 2018 tejadi penurunan RTO sebesar 1.76 kali atau 0.20 dari tahun sebelumnya. Dari hasil tabel perhitungan RTO tahun 2014 sampai dengan tahun 2018 PT. XYZ masih 
ada penurunan yang cukup tertagih. Semakin tinggi tingkat signifikan. Kinerja RTO perusahaan perputaran piutang usaha suatu mencapai titik tertinggi yaitu pada tahun 2017 sebesar 1,96 kali dan perusahaan, maka semakin baik pengelolahan piutang usahanya, dan sebaliknya RTO terendah ditahun 2016 sebesar 1,09 kali, perputaraan piutang usahanya belum dapat meminimalkan jumlah piutang tak juga jika tingkat perputaran piutang usahanya tinggi berarti semakin pendek waktu terikatnya modal dalam piutang usaha.

Average collection period (ACP)

menjadi kas. Hasil yang ditetapkan Rasio ini berfungsi untuk dari perhitungan ini akan mengetahui rata-rata hari yang dihubungkan dengan jumlah hari diperlukan untuk mengumpulkan piutang usaha dan mengubahnya yang ditetapkan sebagai standar kredit perusahaan.

Tahun 2014

$$
\text { Rata }- \text { rata jangka waktu penagihan }=\frac{360 \text { hari }(1 \text { tahun })}{1,77}=203
$$

Tahun 2015

$$
\text { Rata }- \text { rata jangka waktu penagihan }=\frac{360 \text { hari }(1 \text { tahun })}{1,49}=242
$$

Tahun 2016

$$
\text { Rata }- \text { rata jangka waktu penagihan }=\frac{360 \text { hari }(1 \text { tahun })}{1,09}=330
$$

Tahun 2017

$$
\text { Rata }- \text { rata jangka waktu penagihan }=\frac{360 \text { hari }(1 \text { tahun })}{1,96}=184
$$

Tahun 2018

$$
\text { Rata }- \text { rata jangka waktu penagihan }=\frac{360 \text { hari }(1 \text { tahun })}{1,76}=204
$$

Hasil perhitungan average collection period (ACP) dapat dilihat pada tabel berikut: 
Tabel 3 Hasil perhitungan average collection period (ACP)

\begin{tabular}{cccc} 
Tahun & $\begin{array}{c}\text { RTO } \\
\text { (kali) }\end{array}$ & $\begin{array}{c}\text { ACP } \\
\text { (hari) }\end{array}$ & $\begin{array}{c}\text { Perubahan } \\
\text { ACP }\end{array}$ \\
2014 & 1,77 & 203 & - \\
2015 & 1,49 & 242 & 39 \\
2016 & 1,09 & 330 & 88 \\
2017 & 1,96 & 184 & 146 \\
2018 & 1,76 & 204 & 20 \\
\hline
\end{tabular}

Dari hasil tabel di atas terlihat tingkat ACP dari tahun 2014 sampai dengan tahun 2018, perusahaan sangat dipengaruhi oleh tingkat RTO perusahaan. Semakin cepat perputaran piutang usaha RTO maka semakin baik perusahaan dalam mengelola piutang usahanya dan nilai ACP yang lebih rendah menujukan hari pelunasan yang lebih cepat atau lebih baik. Tingkat ACP yang terbaik dari hasil perhitungan tahun 2017 dari tahun 2014 sampai dengan tahun 2018 yaitu sebesar 184 hari, di mana tingkat perputaran piutang usahanya sangat cepat.

Sedangkan tingkat ACP perusahaan yang paling lambat dari hasil perhitungan tahun 2014 sampai dengan tahun 2018 adalah pada tahun 2016 di mana tingkat ACP yang dihasilkan mencapai 330 hari, tingkat perputaran piutang usahanya sangat rendah, yaitu 1,09 kali. Aging of account receivable berfungsi untuk mengukur komposisi bucket account receivable dalam rasio ini bucket account receivable dipisah berdasarkan aging atau umur overdue piutang usaha. Hasil perhitungan aging of account receivable dapat dilihat pada tabel berikut:

Tabel 4 Hasil perhitungan aging of account receivable (dalam presentase)

\begin{tabular}{lccccc}
\multicolumn{1}{c}{ Bucket } & $\mathbf{2 0 1 4}$ & $\mathbf{2 0 1 5}$ & $\mathbf{2 0 1 6}$ & $\mathbf{2 0 1 7}$ & $\mathbf{2 0 1 8}$ \\
Aging $0-30$ & $81,18 \%$ & $68,62 \%$ & $96,2 \%$ & $86,41 \%$ & $77,17 \%$ \\
Aging $31-60$ & $11,55 \%$ & $19,13 \%$ & $0,16 \%$ & $12,84 \%$ & $16 \%$ \\
Aging 60-90 & $-0,06 \%$ & 0 & 0 & $-3,2 \%$ & $3,92 \%$ \\
Aging $91-120$ & $0,22 \%$ & 0 & 0 & 0 & 0 \\
Aging $121+$ & $7,11 \%$ & $12,25 \%$ & $3,64 \%$ & $3,94 \%$ & $2,88 \%$ \\
\hline
\end{tabular}


Aging 0-30 hari, terbaik ditahun 2017 ke 2018 ada penuruan yang terjadi tidak terlalu signifikan yaitu sebesar 9,24\%. Aging 6190 hari, terbaik ditahun 2015 ke 2018 tidak ada penurunan atau kenaikan presentasi yang terjadi dari jumlah piutang usaha yang tak tertagih. Dari tabel aging of account receivable $\mathrm{di}$ atas menunjukan bahwa rasio aging

\section{KESIMPULAN}

Berdasarkan hasil penelitian dan analisis yang dilakukan pada PT. XYZ, Pengendalian internal piutang usaha belum diterapkan dengan baik dalam meminimalkan piutang tak tertagih, estimasi jumlah piutang tak tertagih setiap tahun masih ada peningkatan di tahun 2016 sampai dengan tahun 2018. Penagihan piutang usaha sudah dijalankan sesuai dengan prosedur yang ditentukan oleh manajemen perusahaan. Bagian pemberi fasilitas kredit belum menjalankan tugasnya secara profesional, masih menggunakan metode atau sistem kekeluargaan. PT. XYZ belum dapat meminimalkan piutang tak tertagih dikarenakan masih terjadi

\begin{abstract}
of account receivable tidak mengalami perbaikan dari tahun ke tahun. Hal ini menunjukan bahwa kualitas penagihan tidak mengalami suatu perbaikan, pengendalian internal piutang usaha yang dilakukan oleh perusahaan tidak menunjukan peningkatan yang baik dari tahun ke tahun.
\end{abstract}

peningkatan piutang tak tertagih pada tahun 2016 sampai dengan tahun 2018. Hasil analisis yang dilakukan dengan metode Receivable Turn Over (RTO) dari tahun 2014 sampai dengan tahun 2018 mencapai titik tertinggi yaitu pada tahun 2017 sebesar 1,96 kali dan sebaliknya RTO terendah ditahun 2016 sebesar 1,09 kali. Tingkat Average Collection Period (ACP) terbaik pada tahun 2017 yaitu sebesar 184 hari dan aging of account receivable belum menunjukan hasil yang maksimal dalam meminimalkan piutang tak tertagih. Berdasarkan kesimpulan di atas, saran kepada PT. XYZ yang mungkin bermanfaat dalam mengatasi kelemahan yang terdapat dalam sistem pengendalian 
internal atas piutang usaha. Adapun saran-saran yang dapat berikan adalah sebagai berikut Menjalankan prinsip profesional dalam menjalankan suatu pekerjaan di mana dapat membedakan antara pekerjaan dan keluarga untuk menghindari umur piutang usaha yang terlalu lama. Untuk menciptakan efektivitas yang tinggi terhadap piutang usaha maupun kegiatan perusahaan secara keseluruhan, sebaiknya perusahaan

\section{DAFTAR PUSTAKA}

Ahmed, Riahi Belkaoui. (2015). Teori Akuntansi. Buku 1 Edisi 5. Jakarta: Salemba Empat.

Arens, Alvin A. Randal J. Elder dan Mark S. Beasley. (2015). Auditing dan Jasa Assurance (terjemahan). Edisi 15. Jakarta: Erlangga.

Ayu, Susilowati Dyah. (2017). Analisis Pengendalian Internal Piutang usaha Untuk Meminimalkan Piutang tak tertagih (Bad Debt) Pada PT Indomobil Finance Indonesia Cabang Universitas Semarang. Nuswantoro.

Gunawan, Rendi. (2017). Analisis Sistem Pengendalian Internal atas Piutang usaha Untuk Meminimalkan Jumlah Piutang tak tertagih Pada PT MNC Kabel Mediakom melalukan pemisahaan fungsi dan peran harus diimbangi dengan tenaga kerja harus memiliki kriteria seperti latar belakang pendidikan dan pengalaman kerja untuk membantu mencapai suatu tujuan yang diinginkan perusahaan. Disarankan agar perusahaan dapat menerapkan beberapa metode dalam mengendalikan piutang tak tertagih agar dapat meminimalkan piutang usaha dengan baik.

Hery. (2013). Teori Akuntansi. Lembaga Fakultas Ekonomi. Universitas Indonesia. Jakarta.

Hery. (2016). Akuntansi Dasar 1 dan 2. Jakarta: Grasindo.

Kasmir. (2014). Analisis Laporan

Keuangan. Edisi Satu. Cetakan Ketujuh. Jakarta : PT Raja Grafindo Persada.

Lukman, Syamsuddin. (2011). Manajemen Keuangan Perusahaan. Jakarta: Raja Grafindo Persada.

Mulyadi. (2016). Sistem Akuntansi. Edisi Empat. Jakarta: Salemba Empat. 
Racel, Rompas Ryfan, Inggriani Elim, Gede Suwetja. (2017). Analisis Pengelolaan Piutang usaha dan Kerugian Piutang tak tertagih Pada PT Bank Rakyat Indonesia Cabang. Universitas Sam Ratulangi.

Riwayati, Sri. (2013). Analisis Pengendalian Piutang usaha Terhadap risiko Piutang tak tertagih Pada PT XYZ. Universitas Maritim Raja Ali Haji.

Romney, Marshall B. dan Paul, John Steinbart. (2015). Accounting Information Systems, 13th ed. England: Pearson Education Limited.

Rudianto. (2012). Pengantar Akuntansi Konsep dan Teknik Penyusunan Laporan keuangan. Jakarta: Erlangga.

Sutrisno. (2009). Manajemen Keuangan Teori Konsep dan Aplikasi. Edisi 1. Yogyakarta: Ekonisia.

Syakur, Syafi'I Ahmad. (2015).

Intermediate Accounting. Jakarta: AV Publisher.

Trisnawati, Ernie. Saefullah, Kurniawan. (2010). Pengantar Manajemen. Jakarta: Kencana.

Tuanakotta, Theodorus, M. (2015). Audit Kontemporer, Jakarta: Salemba Empat. 